\title{
Fine-Level Genetic Structure of White Pine Blister Rust Populations
}

\author{
Richard C. Hamelin, Mathieu Dusabenyagasani, and Khalid Et-touil
}

Natural Resources Canada, Canadian Forest Service, Laurentian Forestry Centre, P.O. Box 3800, 1055 du P.E.P.S., Sainte-Foy, QC, G1V 4C7 Canada. Accepted for publication 31 July 1998.

\begin{abstract}
Hamelin, R. C., Dusabenyagasani, M., and Et-touil, K. 1998. Fine-level genetic structure of white pine blister rust populations. Phytopathology $88: 1187-1191$.

The fine-level genetic structure of the white pine blister rust agent, Cronartium ribicola, was investigated by sampling multiple monokaryotic spermogonia directly on cankers in four eastern Canadian white pine (Pinus strobus) plantations and assessing genetic variability, using random amplified polymorphic DNA (RAPD) markers. Ninety-eight percent of the cankers surveyed contained a single DNA haplotype, suggesting spermogonia within cankers are the result of clonal reproduction. A single canker contained two haplotypes that were divided between the upper and lower parts of the canker, suggesting it represented two confluent cankers. In contrast, genotypic diversity was high among cankers.

the total genetic diversity was attributable to sampling of different cankers, strongly suggesting that multiple infections do not take place in the white pine blister rust pathosystem, i.e., a canker is the result of infection by a single genotype. This result is in contrast with the high level of genetic diversity previously reported among dikaryotic aecidia within cankers and is consistent with the hypothesis that variability in the aecidial stage is the result of outcrossing between resident spermogonia and alien spermatia. The genetic structure of the spermogonial stage, which is the vegetative extension of infection by basidiospores and, therefore, the indirect result of meiosis, was consistent with random mating; the observed genotypic diversity was not significantly different $(P>0.05)$ from the genotypic diversity expected under the assumption of panmixis. The results indicate that monokaryotic cankers can be genotyped by sampling a single unopened spermogonia per canker.
\end{abstract} Thirty-seven haplotypes were found among forty-three cankers sampled, and an analysis of molecular variance indicated that $93 \%(P<0.001)$ of
Additional keyword: AMOVA.
White pine blister rust, caused by the basidiomycete Cronartium ribicola J.C. Fisch., is a very severe disease of white pine. The pathogen was introduced into North America during the early twentieth century (30) and has spread to most of the distribution range of white pine. Reforestation and regeneration of white pine are greatly hampered by blister rust in economically important species, such as Pinus strobus, $P$. monticola, and P. lambertiana. Mortality rates of up to $95 \%$ have been reported in white pine plantations in high hazard zones. In addition, some pine species adapted to specialized ecological niches, such as whitebark pine ( $P$. albicaulis), are so vulnerable they are endangered by blister rust $(13,14)$.

An important component of managing blister rust is knowledge about the biology of the pathogen. Early efforts focused on attempts to disrupt the life cycle of the fungus by eradicating the telial host, Ribes spp. (2). Recently, resistance breeding, aided by molecular mapping and selection, has shown promise for helping to manage this disease $(4,21)$. However, many questions remain about the population biology of $C$. ribicola (e.g., the role and contribution of different spore types to the life cycle). Spermatia are apparently strictly sexual uninfective spores that unite two nuclei (28). Aeciospores and urediniospores are presumed to be involved in middle- to long-distance spread. Basidiospores are suspected to be disseminated fairly locally, possibly up to $8 \mathrm{~km}$, depending on topography and wind pattern $(33,34)$. However, such knowledge often is based on circumstantial evidence. Experimental demonstration of these hypotheses is lacking.

Use of molecular methods can provide new means of elucidating the population biology of $C$. ribicola and testing hypotheses concerning infection and dissemination patterns. Four approaches to sampling and analyses have been used to study the population

Corresponding author: R. C. Hamelin; E-mail address: hamelin@cfl.forestry.ca

Publication no. P-1998-0923-01R

(c) 1998 Department of Agriculture and Agri-Food, Government of Canada genetics of pine rusts: (i) direct sampling of single-gall, bulk aeciospore collections combined with isozymes and restriction fragment length polymorphism (RFLP) $(24,32,35-37)$; (ii) direct sampling of single aecidia combined with polymerase chain reaction (PCR)based random amplified polymorphic DNA (RAPD) $(9,10)$; (iii) basidiospore-derived axenic cultures combined with isozymes, RFLP, and RAPD $(5,6,8,15)$; and (iv) direct sampling of single spermogonia with RAPD $(5,6,9,11)$.

With the first approach, codominant markers requiring large amounts of material, such as isozymes and RFLP, can be used, but in heterothallic rusts, the samples can comprise a mosaic of genotypes $(9,18)$, and data interpretation can be difficult $(37)$. In the second approach, PCR-based techniques, mostly dominant RAPD markers, must be used because of the small amount of material available. Because the aecial stage is dikaryotic, analyses are conducted using statistical corrections to account for dominance (10, 20) or, alternatively, using analyses of molecular variance (AMOVA) on phenotypes $(7,9)$. Large numbers of samples can be processed, but exact marker frequencies cannot be obtained. In the third approach, a large amount of material can be grown, and a variety of markers, including codominant isozymes and RFLPs, as well as RAPDs, can be used. Segregation analyses can be conducted because single telia produce a population of sibling progeny $(5,6,8)$. However, the technique can be tedious, and large sample sizes can be difficult to obtain. In addition, selection does not necessarily reflect natural conditions, either on the pine host or growth medium.

The fourth approach is potentially interesting, because spermogonia are the extension of basidiospores, which are the direct result of meiosis. By sampling the fungus directly on the host, it may be possible to study populations of $C$. ribicola resulting from sexual reproduction and test whether the population structure is consistent with the assumptions of random mating. Also, by directly comparing the monokaryotic spermogonial DNA profile (prespermatization) with that of the dikaryotic aecidia (postspermatization), the actual rate of outcrossing of individual cankers can be calculated. 
Knowledge of the fine-level genetic structure of the spermogonial stage also is important to better understand the biology of $C$. ribicola and devise the best sampling strategy for population studies. Comparing the genetic structure obtained by analyzing different spore stages, including aeciospores, urediniospores, spermogonia, and basidiospore-derived cultures, it may be possible to better understand their respective roles in the epidemiology of $C$. ribicola and to assess the effect of host selection pressure on the population structure.

However, genetic variability has been reported among spermogonial drops within cankers in C. ribicola and C. quercuum f. sp. fusiforme $(5,9)$, which is surprising, because it suggests that either there were multiple infections, i.e., a single canker was the result of infection by several genotypes, or heterokaryons were established after dikaryotization. It also is possible that the spermogonial drops were already spermatized at the time of sampling and the observed intracanker variability among monokaryotic spermogonia was, in fact, the result of outcrossing. This could not be

TABLE 1. Random amplified polymorphic DNA haplotypes of Cronartium ribicola spermogonia from four white pine plantations in Quebec Province

\begin{tabular}{|c|c|c|c|}
\hline Canker $^{\mathrm{a}}$ & $n^{\mathrm{b}}$ & Haplotype $^{c}$ & Designation \\
\hline CY101 & 8 & 100101110 & 1 \\
\hline CY102 & 10 & 000111111 & 2 \\
\hline CY21 & 3 & 010101010 & 3 \\
\hline CY22 & 14 & 100101000 & 4 \\
\hline CY23 & 11 & 000111011 & 5 \\
\hline CY28-1 & 4 & 110111100 & 6 \\
\hline CY28-2 & 10 & 100101000 & 4 \\
\hline CY35 & 10 & 010111011 & 7 \\
\hline CY38 & 10 & 100101101 & 8 \\
\hline CY39 & 6 & 010101101 & 9 \\
\hline CY40 & 10 & 010111100 & 10 \\
\hline CY42 & 10 & 000111000 & 11 \\
\hline CY44 & 10 & 101111001 & 12 \\
\hline$\ldots{ }^{\mathrm{d}}$ & $\ldots$ & 001111001 & 13 \\
\hline CY65 & 12 & 100011111 & 14 \\
\hline PL1 & 3 & 001101010 & 15 \\
\hline PL11 & 9 & 100110010 & 16 \\
\hline PL16 & 14 & 000101100 & 17 \\
\hline PL18 & 11 & 100101000 & 4 \\
\hline PL23 & 7 & 110110100 & 18 \\
\hline PL24 & 10 & 000111001 & 19 \\
\hline PL25 & 11 & 110101110 & 20 \\
\hline PL26 & 12 & 001111000 & 21 \\
\hline PL29 & 10 & 000011000 & 22 \\
\hline PL33-1 & 3 & 100111111 & 23 \\
\hline PL33-2 & 5 & 000111000 & 11 \\
\hline PL34 & 9 & 011000110 & 24 \\
\hline PL35 & 9 & 100111010 & 25 \\
\hline PL37 & 9 & 010111000 & 26 \\
\hline PL39 & 5 & 110101001 & 27 \\
\hline PL45 & 7 & 110111001 & 28 \\
\hline PL5 & 3 & 100101111 & 29 \\
\hline PL41 & 9 & 001101010 & 15 \\
\hline $\mathrm{CO} 2$ & 5 & 001101110 & 30 \\
\hline CO6 & 5 & 101100100 & 31 \\
\hline CO11 & 5 & 001111101 & 32 \\
\hline CO18 & 5 & 001111000 & 21 \\
\hline $\mathrm{CO} 20$ & 5 & 101101110 & 33 \\
\hline SB1 & 5 & 011001001 & 34 \\
\hline SB3 & 5 & 011111100 & 35 \\
\hline SB8 & 5 & 101101111 & 36 \\
\hline SB10 & 5 & 100101101 & 8 \\
\hline SB19 & 5 & 100111001 & 37 \\
\hline
\end{tabular}

${ }^{a}$ Letters represent the site $(\mathrm{CY}=$ Saint-Cyprien, $\mathrm{PL}=$ Plessisville, $\mathrm{CO}$ and $\mathrm{SB}=$ two plantations on the Gaspé Peninsula). Numbers represent canker identification.

${ }^{b}$ Number of spermogonia sampled per canker.

${ }^{\mathrm{c}}$ Markers are (Operon primer-size [in base pairs] of marker): OPA01-1700, OPC08-900, OPE15-1600, OPE15-2500, OPK19-2000, OPK19-1700, OPK191500, OPK11-550, and OPK11-900; for conciseness, monomorphic markers are not indicated in the haplotype binary designation.

d Two haplotypes were found within this canker. completely ruled out, because some of the spermogonia were already opened at the time of sampling $(5,9)$.

The objective of this study was to elucidate the fine-level genetic structure of $C$. ribicola populations by sampling unopened monokaryotic spermogonia in a hierarchical fashion (within cankers, among cankers, and among sites) directly on white pine blister rust cankers to determine whether (i) genetic variability occurs among spermogonia within cankers; (ii) the population structure of the spermogonial spore stage is similar to that of the aecidial stage; and (iii) the population structure of spermogonia is consistent with random mating.

\section{MATERIALS AND METHODS}

Sampling. Samples were harvested from cankers in two white pine plantations in south-central Quebec Province (Plessisville [PL], $n=19$; Saint-Cyprien [CY], $n=14$ ), where $C$. ribicola populations have been monitored since 1993, and two plantations on the Gaspé Peninsula in eastern Quebec $(\mathrm{CO}, n=5$; $\mathrm{SB}, n=5)$. A total of 43 cankers was sampled. A single canker was sampled on each tree, except for two trees on which two cankers were sampled. Although some markers differed in frequency between the PL and CY rust populations, expected heterozygosities were relatively small, as were overall genetic differentiations $(9,10)$. Tagged trees with active cankers were observed from the last week of June until the end of July 1996 for appearance of spermogonial blisters. Spermatia were harvested by carefully piercing closed spermogonia with the tip of a Pasteur pipette and collecting the nectar drop in a $1.5-\mathrm{ml}$ Eppendorf microtube containing a $1.5 \mathrm{M}$ sorbitol solution. Samples were kept on ice until processing. Between 3 and 14 single spermogonia, depending on availability of unopened spermogonia, were sampled on each canker, for a total of 324 samples (Table 1). The position of spermogonia on large cankers was noted to identify patterns of distribution of haplotypes within cankers. Spermogonia samples collected in 1994 from cankers that were still active in 1995 were assayed for comparison between years of the same canker.

DNA extraction. DNA was extracted from spermogonia using a modification of a protocol described previously (10). Lyophilized spores were ground for 2 to $4 \mathrm{~min}$ with $\approx 10 \mathrm{mg}$ of diatomaceous earth (Sigma Chemical Co., St. Louis) and $100 \mu \mathrm{l}$ of extraction buffer $(700 \mathrm{mM} \mathrm{NaCl}, 50 \mathrm{mM}$ Tris-HCl [pH 8.0], $10 \mathrm{mM}$ EDTA, $1 \%$ $\beta$-2-mercaptoethanol, $1 \%$ cetyl-trimethyl-ammoniumbromide) with disposable Kontes pestles (VWR-Canlab, Toronto). Extraction buffer $(300 \mu \mathrm{l})$ was added, and samples were incubated at $65^{\circ} \mathrm{C}$ for $1 \mathrm{~h}$.

Samples were extracted with $600 \mu \mathrm{l}$ of chloroform/isoamyl alcohol $(24: 1, \mathrm{vol} / \mathrm{vol})$, vortexed, and centrifuged at $10,000 \times g$ for $5 \mathrm{~min}$. The upper phase was pipetted into 1.5-ml Eppendorf microcentrifuge tubes, and DNA was precipitated by adding $75 \mu$ of $7.5 \mathrm{M}$ ammonium acetate and $600 \mu \mathrm{l}$ of isopropanol and placing the tubes on ice for at least $30 \mathrm{~min}$. DNA was pelleted by centrifugation at $10,000 \times g$ for $5 \mathrm{~min}$ and washed with $70 \%$ ethanol, after which the pellet was air-dried and resuspended in $20 \mu \mathrm{l}$ of TE-8 buffer (10 mM Tris-HCl [pH 8], 1 mM EDTA). DNA concentration was estimated by comparing band intensity on an agarose gel with a set quantity of $\lambda$-HindIII fragments (Gibco-BRL, Gaithersburg, MD). DNA was diluted from 1:2 to 1:25, depending on DNA concentration, and stored in TE- 8 buffer at $-20^{\circ} \mathrm{C}$. Our results indicate that reproducible RAPD patterns were obtained with concentrations of 1 to $100 \mathrm{ng}$.

DNA amplifications. DNA amplifications were performed in $12.5-\mu$ l volumes containing $10 \mathrm{mM}$ Tris- $\mathrm{HCl}(\mathrm{pH} 8.3), 50 \mathrm{mM}$ $\mathrm{KCl}, 2 \mathrm{mM} \mathrm{MgCl}_{2}, 0.0001 \%$ gelatin, $100 \mu \mathrm{M}$ each of dNTP (Pharmacia Biotechnology, Uppsala, Sweden), $0.2 \mu \mathrm{M}$ oligonucleotides, $2 \mu \mathrm{l}(\approx 10 \mathrm{ng})$ of genomic DNA, and 0.5 units of Taq DNA polymerase (Boehringer Mannheim, Laval, QC, Canada) (38). Amplifications were performed in a thermal cycler (model PTC-60, MJ 
Research, Watertown, MA) programmed for denaturation at $94^{\circ} \mathrm{C}$ for $3 \mathrm{~min}$, followed by 1 cycle at $35^{\circ} \mathrm{C}$ for $4 \mathrm{~min}$ and $72^{\circ} \mathrm{C}$ for $2 \mathrm{~min}$, and 45 cycles of $94^{\circ} \mathrm{C}$ for $1 \mathrm{~min}, 35^{\circ} \mathrm{C}$ for $1 \mathrm{~min}$, and $72^{\circ} \mathrm{C}$ for $2 \mathrm{~min}$. Reactions were ended with a 10 -min extension at $72^{\circ} \mathrm{C}$.

Primers (Operon Technologies, Alameda, CA) OPA01 and OPC08 were selected based on previous results $(9,10)$. Additionally, primers OPE15, OPK11, and OPK19 were assayed based on a screening of 60 primers that indicated reproducible polymorphisms in these primers (K. Et-touil and R. C. Hamelin, unpublished data). Amplification products were separated by electrophoresis on $1.5 \%$ agarose gels using $1 \times$ Tris-acetate-EDTA buffer (primer OPA01) or $1 \%$ agarose plus $0.5 \%$ Synergel (Diversified Biotech, Newton Center, MA) in $0.5 \times$ Tris-phosphate-EDTA buffer. PCR products were visualized by UV fluorescence after ethidium bromide staining.

Marker frequencies for OPA01 and OPC08 were reported for $C$. ribicola populations in Quebec (10), including plantations CY and PL sampled in the current study. Mendelian segregation was demonstrated for marker OPK19-1900 in western populations of $C$. ribicola (8). Amplifications of DNA templates and primer combinations were repeated regularly to ensure the reproducibility of amplification profiles. All major diagnostic DNA fragments used in our analysis were reproducible between runs and present in spermogonia, aecidiospores, and urediniospores of C. ribicola $(9,10)$ (R. C. Hamelin, unpublished data).

Data analysis. A matrix of samples $\times$ markers containing a binary scoring for each marker ( 1 for presence, 0 for absence) was recorded. An AMOVA (7) was performed using a matrix of Euclidean distances and Nei and Li's (26) genetic distance between all pairs of haplotypes. The two metric distances yielded similar results, so only the former was used subsequently.

AMOVA uses a classical analysis of variance (ANOVA) approach to compute molecular variance components at different hierarchical levels. The analysis is performed on a matrix of squared molecular distances between pairs of observations, in our case RAPD haplotypes. A conventional sum of squares was calculated as the sum of squared deviations (SSD) between individual observations. The total SSD could be partitioned in a traditional ANOVA framework:

$\operatorname{SSD}($ total $)=\operatorname{SSD}($ among regions $)+$

$\mathrm{SSD}$ (among populations within regions) $+\mathrm{SSD}$ (within population)

and the corresponding mean squared deviations (MSD) were obtained by dividing the SSD by the appropriate degrees of freedom. Variance components were obtained by equating the MSD with its expectations as $\sigma_{a}^{2}$ (among regions), $\sigma_{b}^{2}$ (among populations within groups), and $\sigma_{c}^{2}$ (within populations). $F$ statistic analogs ( $\Phi$ statistics) were calculated as

$$
\Phi_{S T}=\sigma_{a}^{2}+\sigma_{b}^{2} / \sigma^{2}, \Phi_{C T}=\sigma_{a}^{2} / \sigma^{2} \text {, and } \Phi_{S C}=\sigma_{b}^{2} / \sigma_{a}^{2}+\sigma_{b}^{2}
$$

where $\Phi_{S T}$ is the correlation between random haplotypes within populations and random haplotypes drawn from all populations, $\Phi_{C T}$ is the correlation between random haplotypes within regions (east: CO and SB; west: CY and PL) and random haplotypes from all populations, and $\Phi_{S C}$ is the correlation between random haplotypes within populations and random haplotypes within region (7). Nonparametric tests of $\Phi_{S T}, \Phi_{C T}$, and $\Phi_{S C}$ were conducted with 100 random permutations of the data set. The hierarchical level "within cankers" was not included in AMOVA because of the apparent clonality of haplotypes.

The hypothesis of panmixis was tested using analysis of genotypic diversity. The observed genotypic diversity, $\hat{G}(31)$, was calculated using $\hat{G}=1 / \Sigma p^{2}$, where $p$ is the frequency of the $i$ th haplotype in the population. The maximum value for this variable is the sample size. Observed genotypic diversity was compared with the expected genotypic diversity generated assuming random mating and performing 100 simulations using the observed marker frequency. A $t$ statistic was calculated as $t=[G-\hat{G} / \operatorname{var}(G)]$, where $G$ is the mean and $\operatorname{var}(G)$ is the variance determined from the simulations (23). The simulations were performed using a macro written in Microsoft Excel spreadsheet software.

\section{RESULTS}

Of the 43 cankers sampled, $42(97.6 \%)$ were monomorphic with regard to the RAPD profiles of the spermogonia (Table 1; Fig. 1). Even large cankers that spanned more than $0.5 \mathrm{~m}$ and from which 20 spermogonia samples were collected contained unique DNA profiles. Spermogonial DNA profiles also were distinct among cankers sampled on the same tree. The sole canker (CY44; Table 1) in which two haplotypes were found was very large and may have been two confluent cankers. Haplotype 12 was present only on the upper part of canker CY44, and haplotype 13 was present only on the lower part. This canker could not be resampled because the tree died after the 1995 collections.

From 43 cankers sampled, 37 haplotypes of $C$. ribicola were found. Thirty-two haplotypes $(86.5 \%)$ were unique, while five $(13.5 \%)$ occurred more than once. There was no clear association between the occurrence of RAPD markers or haplotypes and the geographic origin of the sample (Table 1). One haplotype (4; Table 1) was represented three times: twice at CY and once at PL, two plantations separated by $\approx 100 \mathrm{~km}$ (Table 1 ; a map is presented in Hamelin et al. [10]). Most of the remaining haplotypes did not occur more than once within a site (Table 1).

Because samples within cankers were apparently clonally derived, cankers, not spermogonia, were considered the sampling unit for subsequent analyses of genetic diversity, avoiding the potential problem of duplicate sampling (23). AMOVA indicated that most of the genetic variability (93\%) was found among cankers within sites and that spermogonial DNA profiles were not significantly more likely to be different among populations $\left(\Phi_{S T}=0.074 ; P=0.096\right.$; Table 2). The proportion of genetic variance between regions (east versus west, separated by $\approx 700 \mathrm{~km}$ ) was significant but not very large $(8 \%)$, and the genetic differentiation index was low but significantly larger than random expectation $\left(\Phi_{C T}=0.085, P<0.001\right)$, whereas the level of genetic differentiation among populations within regions was low and not significant $\left(\Phi_{S C}=-0.011 ; P=0.610\right.$; Table 2). The negative values reported for the variance component among populations within region can be interpreted by analogy to correlation coefficients: haplotypes drawn from different populations within regions were genetically slightly (but not statistically) more related than random haplotypes drawn from the same population.

Observed genotypic diversity, when considering cankers as the sampling unit, was high in all populations sampled (Table 3). The maximum value for this measure of genotypic diversity is the total number of samples. Values observed were close to the sample size

A

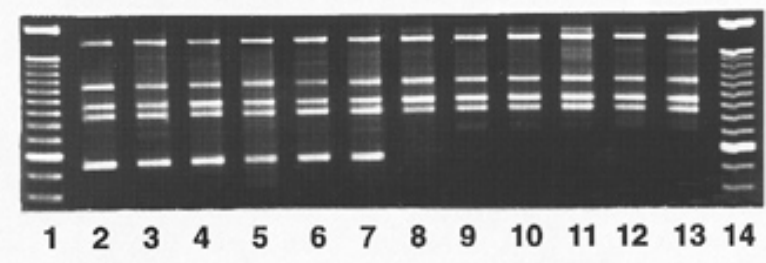

B

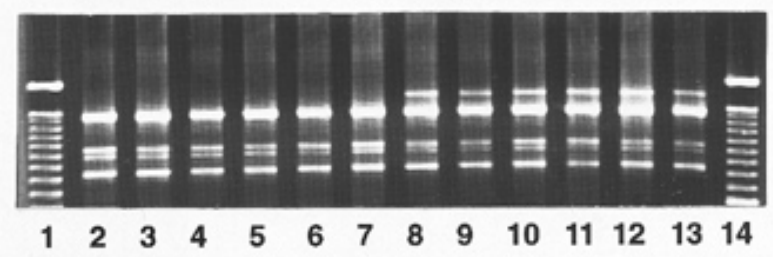

Fig. 1. Random amplified polymorphic DNA of Cronartium ribicola spermogonia, using oligonucleotide primers $\mathbf{A}$, OPK11 and B, OPA01. Lanes 1 and 14, 100-bp ladder; lanes 2 through 7, individual spermogonia samples from canker CY35; and lanes 8 through 13, individual spermogonia samples from canker PL25. 
in all populations. The genotypic frequencies expected under the assumption of random mating also were similar to the observed genotypic frequency and not significantly different, as determined by a $t$ test $(P>0.05$; Table 3$)$. The genetic profiles of cankers sampled in 1994 that were still active in 1995 were compared between years. In all cases, genetic profiles were identical in both years (data not shown).

\section{DISCUSSION}

One of the objectives of this study was to determine whether unspermatized cankers of white pine blister rust comprise more than one monokaryotic haplotype of $C$. ribicola. This question is important because it influences the sampling strategy for conducting population studies on $C$. ribicola. The presence of multiple haplotypes within a canker would imply that multiple infections take place in this pathosystem. The results reported here clearly indicate that spermogonia within a canker are clonal and that an unspermatized canker consists of a single genotype. Furthermore, the high level of genetic diversity within each site, combined with the almost complete absence of genetic diversity within cankers, strongly suggests that multiple infections do not occur in this pathosystem.

This is particularly interesting because infection patterns usually are characterized by multiple spots per needle. Cultures derived from these spots have different genetic profiles (8). The results reported here suggest that a selection process takes place between the time of infection and establishment of a single monokaryotic haplotype that forms a canker. One possible explanation for these results is that once a genotype is present in the infection court, it has the ability to exclude others. The mechanism responsible for this exclusion is unknown.

The monomorphism among spermogonia within cankers reported here is in contrast to previous studies in which some genetic variability was reported among spermogonia within cankers of white pine blister and fusiform rusts $(5,9)$. The discrepancy can be explained by the possibility that spermatization had already occurred at the time of sampling in previous studies. In the study reported here, only unopened spermogonia were sampled, thereby avoiding the potential for contamination or outcrossing. The presence of the DNA markers assayed in the spermogonia, aecidiospores, and urediniospores at similar frequencies strongly suggests that they are not sampling artifacts $(9,10)$ (R. C. Hamelin, unpublished data). In addition, Mendelian segregation was reported for at least one of the markers used in our study (8).

The fine structure of the genetic diversity of the spermogonial phase was in sharp contrast to that of the dikaryotic aecidial phase. Seventy percent of the total genetic diversity was present among aecidia within cankers (9), in contrast to the nearly zero percent reported here, but the proportion of genetic differentiation among

TABLE 2. Analysis of molecular variance of spermogonial samples of Cronartium ribicola from four white pine plantation populations in Quebec Province

\begin{tabular}{|c|c|c|c|c|c|}
\hline Source & df & Variance & $\begin{array}{l}\text { Total var- } \\
\text { iance }(\%)\end{array}$ & $\Phi$ Statistic & $P^{\mathrm{a}}$ \\
\hline Among regions ${ }^{\mathrm{b}}$ & 1 & 0.167 & 8.45 & $\Phi_{C T}=0.085$ & $<0.001$ \\
\hline $\begin{array}{l}\text { Among populations } \\
\text { within region }\end{array}$ & 2 & $-0.020^{\mathrm{c}}$ & $-1.00^{\mathrm{c}}$ & $\Phi_{S C}=-0.011$ & 0.610 \\
\hline $\begin{array}{l}\text { Among cankers } \\
\text { within population }\end{array}$ & 39 & 1.825 & 92.55 & $\Phi_{S T}=0.075$ & $0.097^{\mathrm{d}}$ \\
\hline
\end{tabular}

${ }^{a}$ Probability of a larger value obtained by chance.

b East: CO and SB (two plantations on the Gaspé Peninsula); west: CY (SaintCyprien) and PL (Plessisville).

${ }^{c}$ Negative molecular variance components are possible when values are not significantly different from zero, because the associated fixation index analogs are correlation coefficients. A negative value indicates that haplotypes drawn from different populations are more related than haplotypes drawn from the same population.

${ }^{d}$ The null hypothesis that there is no population structure is not rejected. cankers within and among sites was similar in this and other studies of white pine blister rust that used aecidia $(9,10)$. The impact of these studies on sampling strategy is important, because the probability of obtaining samples with different DNA markers was high when sampling spermogonia or aecidia from different cankers but increased only slightly when sampling new sites or regions (9). The difference in the fine-level genetic structure of aecidia and spermogonia of blister rust can be explained by the fact that the unspermatized canker represents a monokaryon that vegetatively propagates within the host, whereas aecidia are the result of outcrossing between "resident" monokaryotic spermogonia and "alien" spermatia $(8,9,12,28)$.

Low levels of genetic differentiation among geographically separated pine rust populations have been found, using isozymes, RFLP, and RAPD $(8,11,35-37)$. The data have been interpreted primarily as being the result of interpopulation homogenization by longdistance migration. Evidence of long-distance dispersal for rusts is mostly circumstantial, but some cases are well documented for cereal, bean, and poplar leaf rusts $(25,27)$. Aeciospore deposition gradients in fusiform and western gall rusts were fairly steep but were highly dependent on wind and other meteorological factors $(1,29)$. Disease gradients were rather flat for these rusts, possibly due to the long tail in the dispersal gradient or secondary spread. Whether basidiospores, urediniospores, or aeciospores are responsible for gene flow among $C$. ribicola populations remains to be demonstrated.

Because spermogonia are the indirect result of meiosis on the telial host, it was hypothesized that the $C$. ribicola population structure should be consistent with the assumption of random mating. The values reported here strongly support this hypothesis and are consistent with another study that indicated western populations of $C$. ribicola were in Hardy-Weinberg equilibrium (8), in contrast to studies on some ascomycetes in which observed genotypic diversity values were often smaller than values expected under the assumption of random mating $(3,16,17,19,22)$. The difference can be attributed to the presence of mixed mating systems in ascomycetes, with the asexual and sexual stages often occurring concurrently. In contrast, sexually derived basidiospores can only infect the pine host; therefore, any infection occurring on the pine host is the result of meiosis.

From a practical standpoint, the presence of a single monokaryon within cankers of white pine blister means that a canker can be genotyped by collecting a single unopened spermogonial drop per canker. This would allow large population studies to be conducted and, possibly, exhaustive genotyping of entire $C$. ribicola

TABLE 3. Genotypic diversity and random mating in Cronartium ribicola populations from Quebec Province

\begin{tabular}{lcccccc}
\hline Site $^{\mathrm{a}}$ & $\begin{array}{c}\text { No. of } \\
\text { haplotypes }\end{array}$ & $\begin{array}{c}\text { No. of } \\
\text { cankers }\end{array}$ & $\hat{G}^{\mathrm{b}}$ & $G^{\mathrm{c}}$ & $p^{\mathrm{d}}$ & $t^{\mathrm{e}}$ \\
\hline PL & 17 & 19 & 16.200 & 16.721 & 0.84 & $0.273 \mathrm{NS}$ \\
$\mathrm{CY}$ & 14 & $15^{\mathrm{f}}$ & 13.235 & 13.802 & 0.83 & $0.332 \mathrm{NS}$ \\
$\mathrm{CO}$ & 5 & 5 & 5.00 & $\ldots \mathrm{g}^{\mathrm{g}}$ & $\ldots$ & $\ldots$ \\
SB & 5 & 5 & 5.00 & $\ldots$ & $\ldots$ & $\ldots$ \\
Total $^{\mathrm{h}}$ & 37 & 43 & 32.438 & 34.434 & 0.82 & $0.251 \mathrm{NS}$ \\
\hline
\end{tabular}

${ }^{a}$ Letters represent the site $(\mathrm{PL}=$ Plessisville, $\mathrm{CY}=$ Saint-Cyprien, $\mathrm{CO}$ and $\mathrm{SB}=$ two plantations on the Gaspé Peninsula).

b Observed genotypic diversity.

c Mean value of genotypic diversity generated by 100 simulations, using observed frequencies under the assumption of random mating.

d Proportion of simulated distribution with values equal to or larger than the observed genotypic frequency.

e $t$ Statistic calculated as $t=[G-\hat{G} / \operatorname{var}(G)](23)$. NS indicates nont significant at $5 \%$ level.

${ }^{\mathrm{f}}$ For the purpose of this analysis, canker CY44 was assumed to be two confluent cankers.

g Simulations were not performed because the data set was too small.

h Because haplotypes can occur over more than one site, the total number of haplotypes is not equal to the sum of the haplotypes found in individual sites. 
populations in white pine plantations, as well as comparison of the genetic profiles of different spore stages using aecidial sampling $(9,10)$ in addition to basidiospore-derived cultures $(8,15)$. Comparison of genetic profiles will be particularly useful for molecular epidemiology studies of white pine blister rust, for example in investigating the level of outcrossing of individual cankers and studying the spatial relationship of matings.

\section{ACKNOWLEDGMENTS}

We thank L. Côté and J. Dubé for their help with sample collection. J. Bérubé reviewed an earlier version of this manuscript.

\section{LITERATURE CITED}

1. Blenis, P. V., Chang, K. F., and Hiratsuka, Y. 1993. Spore dispersal gradients and disease gradients of western gall rust. Can. J. For. Res. 23: 2481-2486.

2. Boyce, J. S. 1961. Forest Pathology. McGraw-Hill, Toronto.

3. Cubeta, M. A., Cody, B. R., Kohli, Y., and Kohn, L. M. 1997. Clonality in Sclerotinia sclerotiorum on infected cabbage in eastern North Carolina. Phytopathology 87:1000-1004.

4. Dewey, M. E., Delfino-Mix, A., Kinloch, B. B., Jr., and Neale, D. B. 1995. Random amplified polymorphic DNA markers tightly linked to a gene for resistance to white pine blister rust in sugar pine. Proc. Natl. Acad. Sci. USA 92:2066-2070.

5. Doudrick, R. L., Nance, W. L., Nelson, C. D., Snow, G. A., and Hamelin, R. C. 1993. Detection of DNA polymorphisms in a single urediniosporederived culture of Cronartium quercuum f. sp. fusiforme. Phytopathology 83:388-392.

6. Doudrick, R. L., Nelson, C. D., and Nance, W. L. 1993. Genetic analysis of single urediniospore culture of Cronartium quercuum f. sp. fusiforme, using random amplified polymorphic DNA markers. Mycologia 85:902911.

7. Excoffier, L., Smouse, P. E., and Quattro, J. M. 1992. Analysis of molecular variance inferred from metric distances among DNA haplotypes: Application to human mitochondrial DNA restriction data. Genetics 131: 479-491.

8. Gitzendanner, M. A., White, E. E., Foord, B. M., Dupper, G. E., Hodgskiss, P. D., and Kinloch, B. B., Jr. 1996. Genetics of Cronartium ribicola. III. Mating system. Can. J. Bot. 74:1852-1859.

9. Hamelin, R. C. 1996. Genetic diversity between and within cankers of the white pine blister rust. Phytopathology 86:875-879.

10. Hamelin, R. C., Beaulieu, J., and Plourde, A. 1995. Genetic diversity in populations of Cronartium ribicola in plantations and natural stands of Pinus strobus. Theor. Appl. Genet. 91:1214-1221.

11. Hamelin, R. C., Doudrick, R. L., and Nance, W. L. 1994. Genetic diversity in Cronartium quercuum f. sp. fusiforme on loblolly pines in southern U.S. Curr. Genet. 26:359-363.

12. Hunt, R. S. 1985. Experimental evidence of heterothallism in Cronartium ribicola. Can. J. Bot. 63:1086-1088.

13. Keane, R. E., and Arno, S. F. 1993. Rapid decline of whitebark pine in western Montana: Evidence from 20-year remeasurements. West. J. Appl. For. 8:44-47.

14. Keane, R. E., Morgan, P., and Menakis, J. P. 1994. Landscape assessment of the decline of whitebark pine (Pinus albicaulis) in the Bob Marshall Wilderness Complex, Montana, USA. Northwest Sci. 68:213-229.

15. Kinloch, B. B., Jr., and Dupper, G. E. 1996. Genetics of Cronartium ribicola. I. Axenic culture of haploid clones. Can. J. Bot. 74:456-460.

16. Koenig, R. L., Ploetz, R. C., and Kistler, H. C. 1997. Fusarium oxy- sporum f. sp. cubsense consists of a small number of divergent and globally distributed clonal lineages. Phytopathology 87:915-923.

17. Kohli, Y., Brunner, L. J., Yoell, H., Milgroom, M. G., Anderson, J. B., Morrall, R. A. A., and Kohn, L. M. 1995. Clonal dispersal and spatial mixing in populations of the plant pathogenic fungus, Sclerotinia sclerotiorum. Mol. Ecol. 4:69-77.

18. Kuhlman, E. G., and Matthews, F. R. 1993. Variation in virulence among single-aeciospore isolates from single-gall isolates of Cronartium quercuum f. sp. fusiforme. Can. J. For. Res. 23:67-71

19. Liu, Y.-C., Cortesi, P., Double, M. L., MacDonald, W. L., and Milgroom, M. G. 1996. Diversity and multilocus genetic structure in populations of Cryphonectria parasitica. Phytopathology 86:1344-1351.

20. Lynch, M., and Milligan, B. G. 1994. Analysis of population genetic structure with RAPD markers. Mol. Ecol. 3:91-99.

21. Meagher, M. D., and Hunt, R. S. 1996. Heritability and gain of reduced spotting vs. blister rust on western white pine in British Columbia, Canada. Silvae Genet. 45:75-81.

22. Milgroom, M. G. 1996. Recombination and the multilocus structure of fungal populations. Annu. Rev. Phytopathol. 34:457-477.

23. Milgroom, M. G., Lipari, S. E., and Powell, W. A. 1992. DNA fingerprinting and analysis of population structure in the chestnut blight fungus, Cryphonectria parasitica. Genetics 131:297-306.

24. Moricca, S., Kasuga, T., Mitchelson, K., Ragazzi, A., and Diamandis, S. 1996. Heterogeneity in intergenic regions of the ribosomal repeat of the pine-blister rusts Cronartium flaccidum and Peridermium pini. Curr. Genet. 29:388-394.

25. Nagarajan, S., and Singh, D. V. 1990. Long-distance dispersion of rust pathogens. Annu. Rev. Phytopathol. 28:139-153.

26. Nei, M., and Li, W. H. 1979. Mathematical model for studying genetic variation in terms of restriction endonucleases. Proc. Natl. Acad. Sci. USA 76:5269-5273.

27. Pedgley, D. E. 1986. Long distance transport of spores. Pages 346-365 in: Long Distance Transport of Spores. K. J. Leonard, W. E. Fry, eds. Macmillan Publishing Company, New York.

28. Pierson, J. M. 1933. Fusion of pycniospores with filamentous hyphae in the pycnium of the white pine blister rust. Nature (Lond.) 131:728-729.

29. Schmidt, R. A., Carey, W. A., and Hollis, C. A. 1982. Disease gradients of fusiform rust on oak seedlings exposed to a natural source of aeciospore inoculum. Phytopathology 72:1485-1489.

30. Spaulding, P. 1914. New facts concerning the white-pine blister rust. Bull. U.S. Dep. Agric. 116:1-8.

31. Stoddart, J. A., and Taylor, J. F. 1988. Genotypic diversity: Estimation and prediction in samples. Genetics 118:705-711.

32. Tuskan, G. A., and Walla, J. A. 1989. Isozyme characterization of Peridermium harknessii and Cronartium quercuum f. sp. banksianae with starch gel electrophoresis. Phytopathology 79:444-448.

33. Van Arsdel, E. P. 1958. Smoke movement clarifies spread of blister rust from Ribes to distant white pine. Am. Meteorol. Soc. Bull. 39:442-443.

34. Van Arsdel, E. P. 1965. Micrometeorology and plant disease epidemiology. Phytopathology 55:945-950.

35. Vogler, D. R., Cobb, F. W., Jr., Geils, B. W., and Nelson, D. L. 1996. Isozyme diversity among hard pine stem rust fungi in the western United States. Can. J. Bot. 74:1058-1070.

36. Vogler, D. R., Kinloch, B. B., Jr., Cobb, F. W., Jr., and Popenuck, T. L. 1991. Isozyme structure of Peridermium harknessii in the western United States. Can. J. Bot. 69:2434-2441.

37. White, E. E., Foord, B. M., and Kinloch, B. B., Jr. 1996. Genetics of Cronartium ribicola. II. Variation in the ribosomal gene cluster. Can. J. Bot. 74:461-468.

38. Williams, J. G. K., Kubelik, A. R., Livak, K. J., Rafalski, J. A., and Tingey, S. V. 1990. DNA polymorphisms amplified by arbitrary primers are useful as genetic markers. Nucleic Acids Res. 18:6531-6535. 